\title{
SPECTROSCOPIC STUDIES OF CU (II) AND CO (II) COMPLEXES WITH RUTIN IN SOLUTIONS
}

\section{O.K. Trunova*, M.S. Artamonov, T.O. Makotryk}

V.I. Vernadsky Institute of General and Inorganic Chemistry of the National Academy of Sciences of Ukraine, 32/34 Academic Palladin ave., Kyiv 03142, Ukraine

*e-mail:trelkon@gmail.com

Complexation in $\mathrm{M}(\mathrm{II})$ - Rut systems $(\mathrm{M}(\mathrm{II})=\mathrm{Co}, \mathrm{Cu})$ was studied by electron absorption spectroscopy and $\mathrm{pH}$-metric titration in water-ethanol solutions depending on the metal: ligand ratio $(1: 1 ; 2: 1)$ and the $\mathrm{pH}$ of the medium. It was shown that the structure and stoichiometric composition of the complexation reaction products are influenced by such basic parameters as L:M and the $\mathrm{pH}$ value of the medium. Depending on the $\mathrm{pH}$ value, chelation involves certain binding sites, which primarily is associated with the redistribution of the electron density in the flavonoid molecule. In a weakly acidic or neutral medium, regardless of the $\mathrm{M}(\mathrm{II})$ : Rut ratio, the formation of monoligand complexes of rutin with 3-d metals occurs with the participation of $5-\mathrm{OH}$ and $4-\mathrm{C}=\mathrm{O}$ fragments of the $\mathrm{A}$ and $\mathrm{C}$ rings, and in an alkaline medium, chelation proceeds on the catecholic fragment of ring $\mathrm{B}$ rutin. Biligand complexes are formed with the participation of the gydroxo groups of the catechol fragment of each rutin molecule, and the formation of compounds with a ratio of 2:1 occurs both due to $5-\mathrm{OH}$ and $4 \mathrm{C}=\mathrm{O}$ and due to 3 ', 4'-OH groups. The calculated values of the stability constants of the complexes showed that the stability of the Co (II) complexes is several orders of magnitude lower than the stability of the corresponding $\mathrm{Cu}$ (II) complexes.

Keywords: complexes, copper, cobalt, rutin, flavonoids, absorption spectra.

INTRODUCTION. Flavonoids are a large class of natural low-molecular-weight polyphenolic compounds of the general $\mathrm{C}_{6}-\mathrm{C}_{3}-\mathrm{C}_{6}$ carbon skeleton formula, as well as their derivatives, which are characterized by high biological activity and low toxicity. The targeted biological action of flavonoids is related to the physicochemical properties of various structures, including conformations of molecules, the presence of which provides, for example, radioprotective and antioxidant properties. Flavonoids are widely used in plants, in which they play several very important functions, including antioxidant one [1-5]. Rutin (3, 3', 4', 5,7-pentahydroxyflavone-3-rhamnoglucoside $\mathrm{C}_{27} \mathrm{H}_{26} \mathrm{O}_{16} \mathrm{H}_{4}, \mathrm{H}_{4} \mathrm{~L}$, Rut) is a natural flavonoid of the flavonol type, consisting of the flavonol quercetin and the rutinose disaccharide (rhamnose and glucose): 


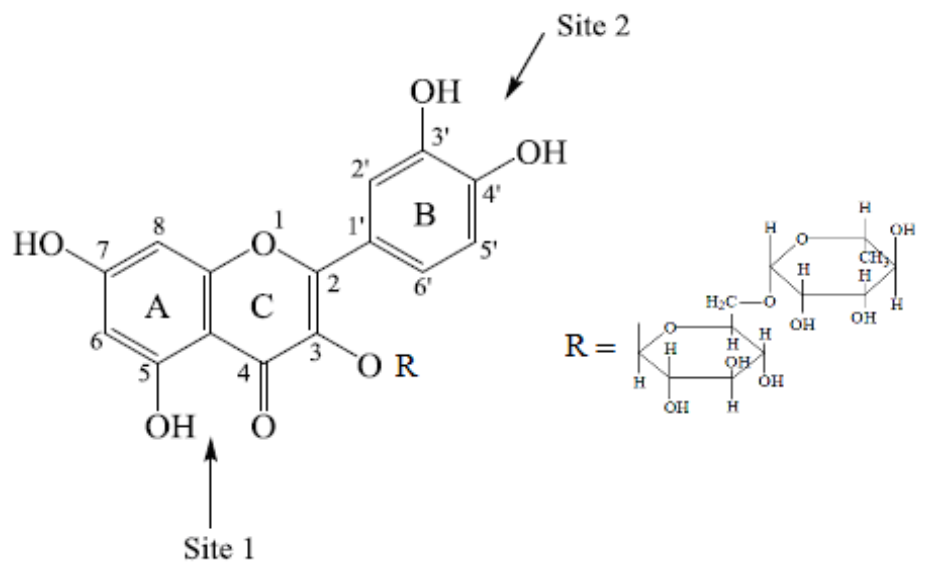

Fig. 1. The structure of the rutin molecule.

It exhibits high biological and pharmacological activity (antioxidant, anti-inflammatory, antiviral, antimicrobial, etc.) [6-12]. Due to its medicinal properties, rutin is widely used as a component of many pharmaceuticals (eg, vitamin P). The most important structural elements of rutin, which determine its properties, are: o-dihydroxo group in the B-cycle (catechol structure) as a potential radical label; the double bond between positions 2 and 3 of the C-cycle is conjugated with the keto group at position 4 (due to the ability to delocalize the unpaired electron of the flavonoid radical) and C-3, C-5 and C-7 hydroxyl groups ( $\mathrm{C}$ and A cycles) as potential acceptors of free radicals $[13,14]$.

Flavonoids bind metal ions well, forming chelate complexes, which is of great importance for the analytical and pharmaceutical use of these compounds. The formation of different CS structures of flavonoids with metal ions with the stoichiometric composition L: M from 1: 2 to 2: 1 depends on the binding sites that participate in the reaction. As can be seen from the structure of the rutin molecule, in complexes with metals, this flavonoid has two potential centers for coordination to metal ions: $5-\mathrm{OH}$ and $4-\mathrm{C}=\mathrm{O}, 3^{\prime}-\mathrm{OH}$ and $4^{\prime}-\mathrm{OH}$ (Fig. 1). Most metal ions are able to form complexes with rutin in a wide range of $\mathrm{pH}(2-10)$, the stereochemistry of which strongly depends on the acidity of the solutions [15-17]. The best complexation occurs at $\mathrm{pH} 4-8$, because at $\mathrm{pH}<4$ rutin is in undissociated form (weak acid), and at $\mathrm{pH}>8$ there is the formation of stoichiometrically different coordination compounds or dissociation of existing complexes. In aqueous solutions, the complexes are poorly soluble, so, as a rule, they are investigated in the form of solid compounds.

Considerable attention in the study of flavonoids is paid to complexes with transition metals, which can be used for the prevention and treatment of many diseases $[15,18,19]$. Studies of flavonoids in oxidative processes show that the formation of chelates gives them antioxidant properties, which are more effective in binding free radicals [20-22]. In [20] it was shown that rutin complexes with iron, copper and zinc show increased efficiency in the absorption of free radicals, the most effective of which is the copper complex. The rutin com- 
plex with copper has a greater ability to retard the oxidation process, and rutin complexes with iron(II) and copper(II) are more effective in removing free radicals compared to pure rutin $[23,24]$.

It should be noted that rutin and its complexes due to poor solubility in water and body fluids have a very low bioavailability in the body, which limits the use of their useful pharmacological properties. Increased solubility can be achieved by using other solvents that will also be non-toxic to living organisms. The literature mainly investigates the complexation of rutin with metals in methanol solutions, DMSO or mixtures of different organic solvents [23, 2528 ]. Since rutin is poorly soluble in water, but better soluble in ethanol $\left(0.66 \cdot 10^{-5} \mathrm{~mol} / \mathrm{dm}^{3}\right.$ and $436.5 \cdot 10^{-5} \mathrm{~mol} / \mathrm{dm}^{3}$, respectively) $[1,29$, 30], for the potential application of its useful properties in pharmacology, there is a need to investigate the properties of rutin and its complexes with $\mathrm{Cu}$ (II) and Co (II) in aqueousethanolic solutions. The choice of metal ions is due to their role in the life of organisms. Copper and cobalt are transition metals and essential trace elements. $\mathrm{Cu}$ (II) is part of many vitamins, hormones, enzymes, respiratory pigments, is involved in metabolic processes, tissue respiration and more. Copper ions play an important role of cofactors in living systems, so the presence of competing complexing agents can affect their biological activity [20,31], Co (II) is present in vitamin B12, is involved in enzymatic processes and hormone synthesis [31]. Therefore, the aim of this work is to study the acid-base forms of rutin depending on the $\mathrm{pH}$ of the solution and its complexation with $\mathrm{Cu}(\mathrm{II})$ and $\mathrm{Co}(\mathrm{II})$ in aqueous-ethanol solutions by $\mathrm{pH}$-metric titration and electron absorption spectroscopy.
EXPERIMENT AND DISCUSSION OF THE RESULTS. The study of the complexation of $\mathrm{Cu}(\mathrm{II})$ and $\mathrm{Co}(\mathrm{II})$ ions with rutin was carried out in water-ethanol solutions (1:2) depending on $\mathrm{pH}(\sim 2 \div 11)$ and the metal:ligand ratio. Inorganic salts of 3-d metals were used as starting compounds: cobalt chloride $\mathrm{CoCl}_{2} \cdot 6 \mathrm{H}_{2} \mathrm{O}$ (analytical grade) and copper sulfate $\mathrm{CuSO}_{4} \cdot 5 \mathrm{H}_{2} \mathrm{O}$ (analytical grade). Rutin manufactured by Sigma- Aldrich was used without further purification.

The exact concentration of metal ions was determined by complexometric titration [32]. Working solutions of rutin were prepared using a precisely weighed sample. Potentiometric titration was carried out with a $0,1 \mathrm{M}$ solution of alkali $(\mathrm{NaOH})$ or acid $(\mathrm{HCl})$ as a titrant. The $\mathrm{pH}$ value was recorded on a Mettler Toledo Seven Easy pH meter (accuracy $\pm 0.05)$ at $20 \pm 3{ }^{\circ} \mathrm{C}$ and constant ionic strength $\mu=0,1 \mathrm{M}\left(\mathrm{KNO}_{3}\right)$. Electronic absorption spectra were recorded on a UV/VIS Specord 210 Plus spectrophotometer (Analytik Jena AG) in quartz cuvettes with $l=1 \mathrm{~cm}$ (measurement range 190-1100 nm; relative error in the measurement of optical density $\pm 0,005$ ). A series of $\mathrm{Co}(\mathrm{II})$ and $\mathrm{Cu}(\mathrm{II})$ solutions with rutin was studied at a concentration of $1 \cdot 10^{-4} \mathrm{M}$ and the ratio M:Rut $=1: 1,2: 1$. The comparison solution is water. To establish the stoichiometric composition and stability of the formed complexes, the method of equilibrium displacement was used [33]. Step constants of complex formation were determined by the titration of a solution containing known amounts of C (II) chloride C (II) sulfate and rutin with an acid/alkali solution.

In the electronic absorption spectrum of an aqueous ethanolic solution of rutin (Fig. 2) there are two absorption bands, which are 
due to intramolecular $\pi \rightarrow \pi *$ transitions: the first band with a maximum in the area of 327-408 nm corresponds to the absorption of a cynnamoyl fragment of the molecule associated with a conjugated system between $\mathrm{cy}$ - cle B and a carbonyl fragment of cycle $\mathrm{C}$. The second absorption band in the region of 250 $290 \mathrm{~nm}$ refers to $\pi \rightarrow \pi^{*}$ transitions in the A ring benzoyl fragment [34]

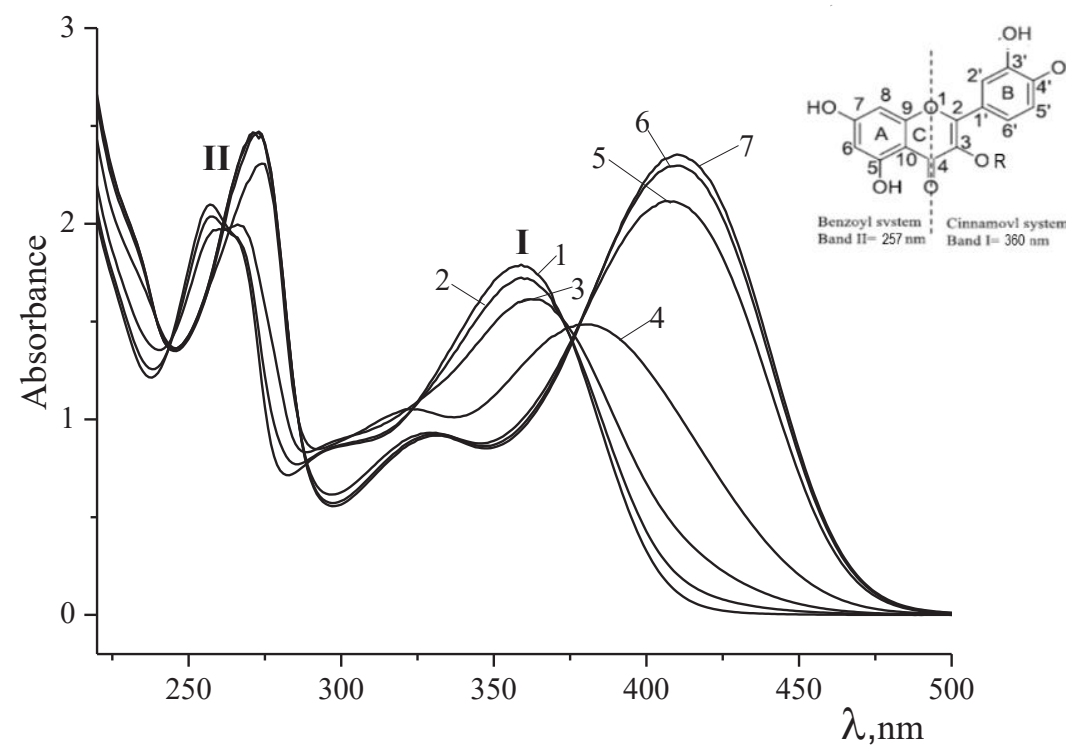

Fig. 2. UV absorption spectrum of an aqueous-ethanol solution of rutin at $\mathrm{pH}$ : 1. - 5.6; 2. - 6.3; 3. - 7.0; 4. - 8.2; 5. - 9.7; 6. - 10.4; 7. - 11.4.

The gradual bathochromic shift at $\mathrm{pH}>6$ is associated with the formation of differently protonated forms of rutin, which are in dynamic equilibrium depending on the acidity of the solutions. In the acidic $\mathrm{pH}$ range, there is a bathochromic shift of absorption band II with the formation of a shoulder at $290 \mathrm{~nm}$, which disappears at $\mathrm{pH} 7$. At the same time, there is a bathochromic shift of the band I maximum (357 $\mathrm{nm} \rightarrow 363 \mathrm{~nm})$, which is accompanied by a hypochromic effect. Such changes may be related to the dissociation of the $\mathrm{OH}$ group at position 7 of cycle $\mathrm{A}$ of the rutin molecule. At $\mathrm{pH}=7.74$ there are a hypsochromic shift and an increase in the opti- cal density of the solution, which indicates the further dissociation of proton rutin. At $\mathrm{pH}=9.65$, the optical properties of the system change significantly - two absorption maxima are clearly manifested at $\lambda_{\max }=329 \mathrm{~nm}$ and $407 \mathrm{~nm}$. At pH = 11.90, a hypsochromic shift of these absorption maxima is observed, which may be associated with partial oxidation of rutin.

According to spectrophotometric titration, the dissociation constants of rutin and the distribution of acid-base forms of rutin depending on the $\mathrm{pH}$ of the solution were calculated using the mathematical program CLINP 2.1 [35] (tab. 1, fig. 3, respectively). 
Table 1 It should be noted that the calculated disso-

Values of rutin dissociation constants in an aqueous ethanol solution.

\begin{tabular}{ccc}
\hline \hline $\begin{array}{c}\text { Dissociation } \\
\text { stage }\end{array}$ & $\mathrm{pK}$ & $\begin{array}{c}\text { Dissociating } \\
\text { group }\end{array}$ \\
\hline $\mathrm{H}_{4} \mathrm{~L} \leftrightarrow \mathrm{H}_{3} \mathrm{~L}^{-}+\mathrm{H}^{+}$ & $8,17 \pm 0,15$ & $7-\mathrm{OH}$ \\
$\mathrm{H}_{3} \mathrm{~L}^{-} \leftrightarrow \mathrm{H}_{2} \mathrm{~L}^{2-}+\mathrm{H}^{+}$ & $9,63 \pm 0,16$ & $3^{\prime}-\mathrm{OH}$ \\
$\mathrm{H}_{2} \mathrm{~L}^{2-} \leftrightarrow \mathrm{HL}^{3-}+\mathrm{H}^{+}$ & $10,76 \pm 0,14$ & $5-\mathrm{OH}$ \\
$\mathrm{HL}^{3-} \leftrightarrow \mathrm{L}^{4-}+\mathrm{H}^{+}$ & $11,85 \pm 0,26$ & $4 '-\mathrm{OH}$ \\
\hline \hline
\end{tabular}

ciation constants of the $\mathrm{OH}$ groups of rutin differ slightly from the $\mathrm{pK}$ values given in $[36,37]$ due to the use of different solvents (methanol or water)

Thus, the analysis of electronic absorption spectra shows that the dissociation of the hydroxyl groups of rutin in aqueous-ethanolic solutions takes place in the order: $7-\mathrm{OH}$, $3^{\prime}-\mathrm{OH}, 5-\mathrm{OH}, 4^{\prime}-\mathrm{OH}$.

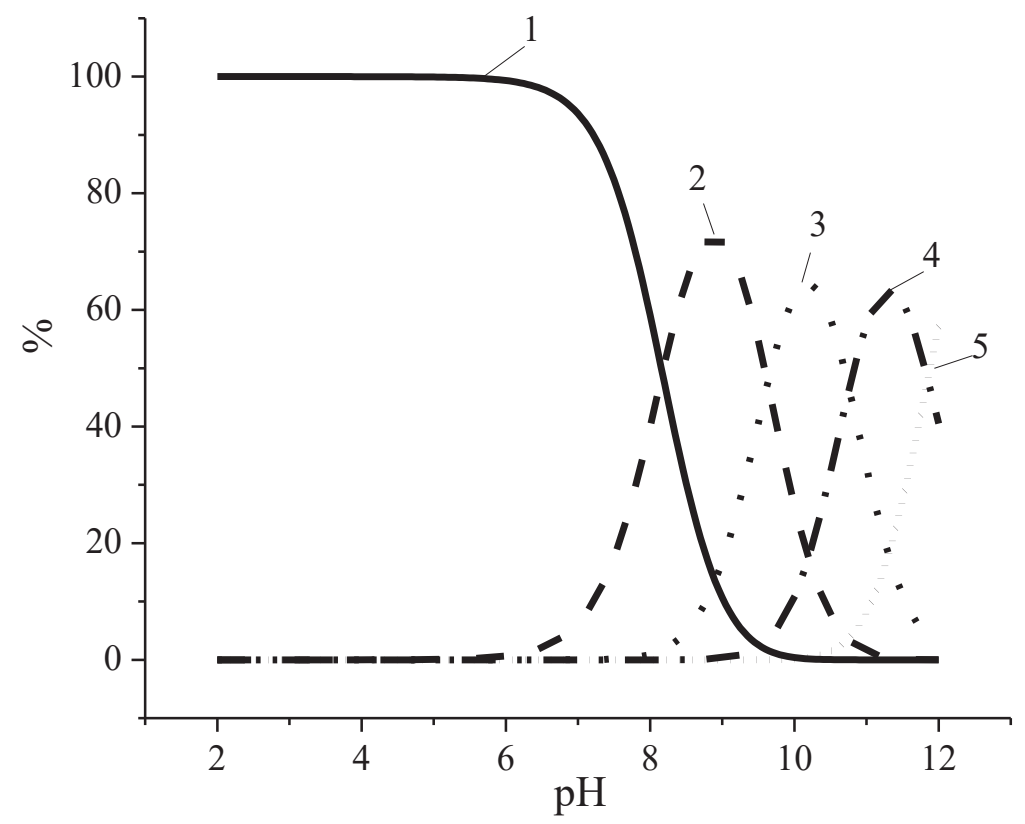

Fig.3 Dissociation diagram of rutin: $\mathrm{H}_{4} \mathrm{~L}$ undissociated form of rutin (1); $\mathrm{H}_{3} \mathrm{~L}^{-}(2) ; \mathrm{H}_{2} \mathrm{~L}^{2-}$ (3); $\mathrm{HL}^{3-}$ (4), $\mathrm{L}^{4-}(5)$.

The study of complex formation processes of rutin with $\mathrm{Co}$ (II) and $\mathrm{Cu}$ (II) ions was performed by $\mathrm{pH}$-potentiometric titration. Figure 4 shows titration curves of the Co(II):Rut (a) and $\mathrm{Cu}(\mathrm{II})$ :Rut (b) systems, which are in a more acidic $\mathrm{pH}$ range relative to the critical titration of rutin, which is associated with the formation of metal complexes with functional groups Rut (carbonyl $-\mathrm{CO}=$ or $-\mathrm{OH}$ ). The titration curves of cobalt and copper systems at M: Rut $=1: 1$ (Fig. 4, curves 2) have almost the same appearance: two poorly defined buffer regions ( $\mathrm{pH} \sim 6-8$ and 8-10) and a blurred jump at $\mathrm{pH} \sim 10$. It is likely that tapered complexes are formed in a more acidic medium in which the metals are bonded to the 5-hydroxyl and 4-carbonyl groups of rings $\mathrm{A}$ and $\mathrm{C}$. In an alkaline medium, the metals are bonded to the deprotonated hydroxyls of the catechol moiety. The titration curve of the system 
$\mathrm{Cu}(\mathrm{II})$ :Rut $=2: 1$ (Fig. 4, curve 3) has two distinct jumps ( $\mathrm{pH} 5.5$ and 9), shifted to a more acidic $\mathrm{pH}$ region compared to the equimolar system. Under these conditions, the interac- tion of a copper ion with the $3^{\prime}-4^{\prime}$-hydroxyl groups of the ring $\mathrm{B}$ of two rutin molecules is possible similar to the interaction of $\mathrm{Cu}$ (II) with quercetin [38].

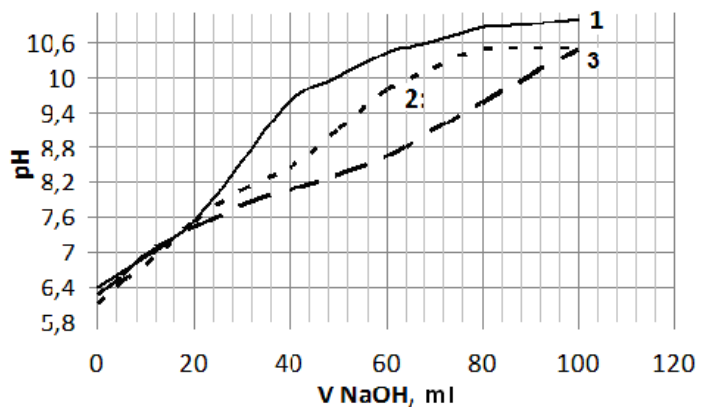

a

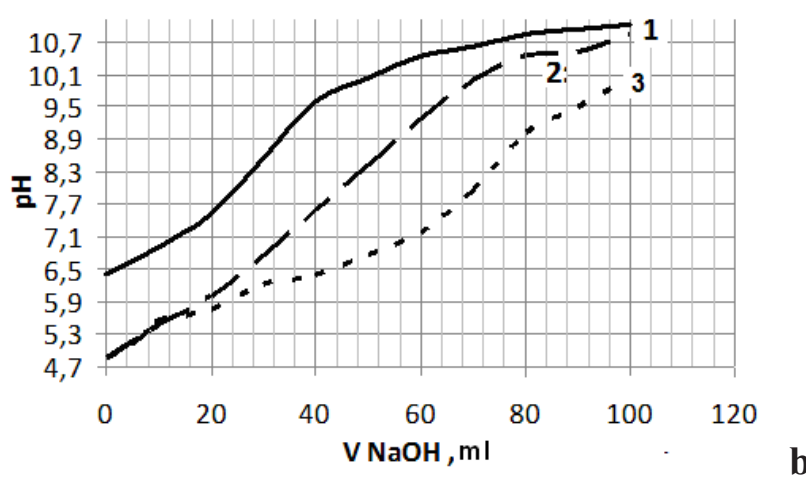

Fig. 4. Curves of pH-metric titration of the systems $\mathrm{Co}(\mathrm{II})$ :Rut (a) and $\mathrm{Cu}$ (II):Rut (b): 1. - Rut; 2. $\mathrm{M}:$ Rut $=1: 1 ; 3 .-\mathrm{M}:$ Rut $=2: 1$.

Based on the obtained titration curves, the concentration of the free ligand $\left[\mathrm{L}^{-}\right]$and the formation function were calculated using the formulas:

$$
\begin{gathered}
-\lg \left[\mathrm{L}^{-}\right]=\mathrm{p} k_{a}-\mathrm{p} a_{\mathrm{H}+}-\lg \left(C_{L}-C_{T}-a_{\mathrm{H}+}\right), \\
\tilde{n}=\left(C_{\mathrm{T}}+a_{\mathrm{H}+}-\left[\mathrm{L}^{-}\right]\right) / C_{M^{\prime}}
\end{gathered}
$$

where $\mathrm{C}_{\mathrm{L}}$ - the total ligand concentration, $\mathrm{C}_{\mathrm{M}}-$ the total metal concentration, $\mathrm{C}_{\mathrm{T}}$ - the concentration of added titrant, $a_{\mathrm{H}+}$ - the activity of hydrogen ions, $k_{a}$ - the acid dissociation constant of rutin.

Based on the values of $\tilde{n}$ according to the Bjerrum method [39] stepwise stability constants of complexes of cobalt and copper with rutin are calculated (Table 2).

The stability of $\mathrm{Co}$ (II) complexes is several orders of magnitude lower than the stability of copper complexes, which is obviously due to the high affinity of $\mathrm{Cu}^{2+}$ for rutin donor oxygen atoms, and especially for the ortho-dihydroxyl group [34].

Table 2

The calculated values of the stability constants of complexes of $\mathrm{Co}$ (II) and Cu (II) with rutin*.

\begin{tabular}{c|c|c}
\hline \hline Metals & M: Rut & $\lg \beta$ \\
\hline \multirow{2}{*}{$\mathrm{Co}^{2+}$} & $1: 1$ & $8,85 \pm 0,05$ \\
& $2: 1$ & $8,16 \pm 0,07$ \\
$\mathrm{Cu}^{2+}$ & $1: 1$ & $18,51 \pm 0,08$ \\
& $2: 1$ & $11,76 \pm 0,05$ \\
\hline \hline
\end{tabular}

${ }^{*} g \beta$ is given for the form of complexes $[M L]$ and $\left[M_{2} L\right]$

The complexation of rutin with $\mathrm{Co}$ (II) and $\mathrm{Cu}$ (II) ions was analyzed using electronic absorption spectra in the ultraviolet and visible regions depending on $\mathrm{pH}$ (fig. $5, \mathrm{a}, \mathrm{b}$ )

In the spectra of all studied systems with a change in $\mathrm{pH}$ and the ratio of components, there are a change in the optical density of solutions and a bathochromic shift of the absorption maxima of bands I and II in complexes relative to their position in the spectra of 
pure rutin. This indicates complexation in $\mathrm{M}$ : sociates with the formation of a flavonolate ion Rut systems. It should be noted that in acidic and can interact with the metal-complexing media $(\mathrm{pH}<4)$ rutin is in the protonated form $\mathrm{H}_{4} \mathrm{~L}$, the participation of which in complexation is not possible. At $\mathrm{pH} \geq 6$, rutin turns into an electron-donating form, which further disagent. The largest bathochromic shift $\lambda \max$ for all studied systems occurs at $\mathrm{pH} \geq 5.5$ due to the involvement in chelation of different binding sites.
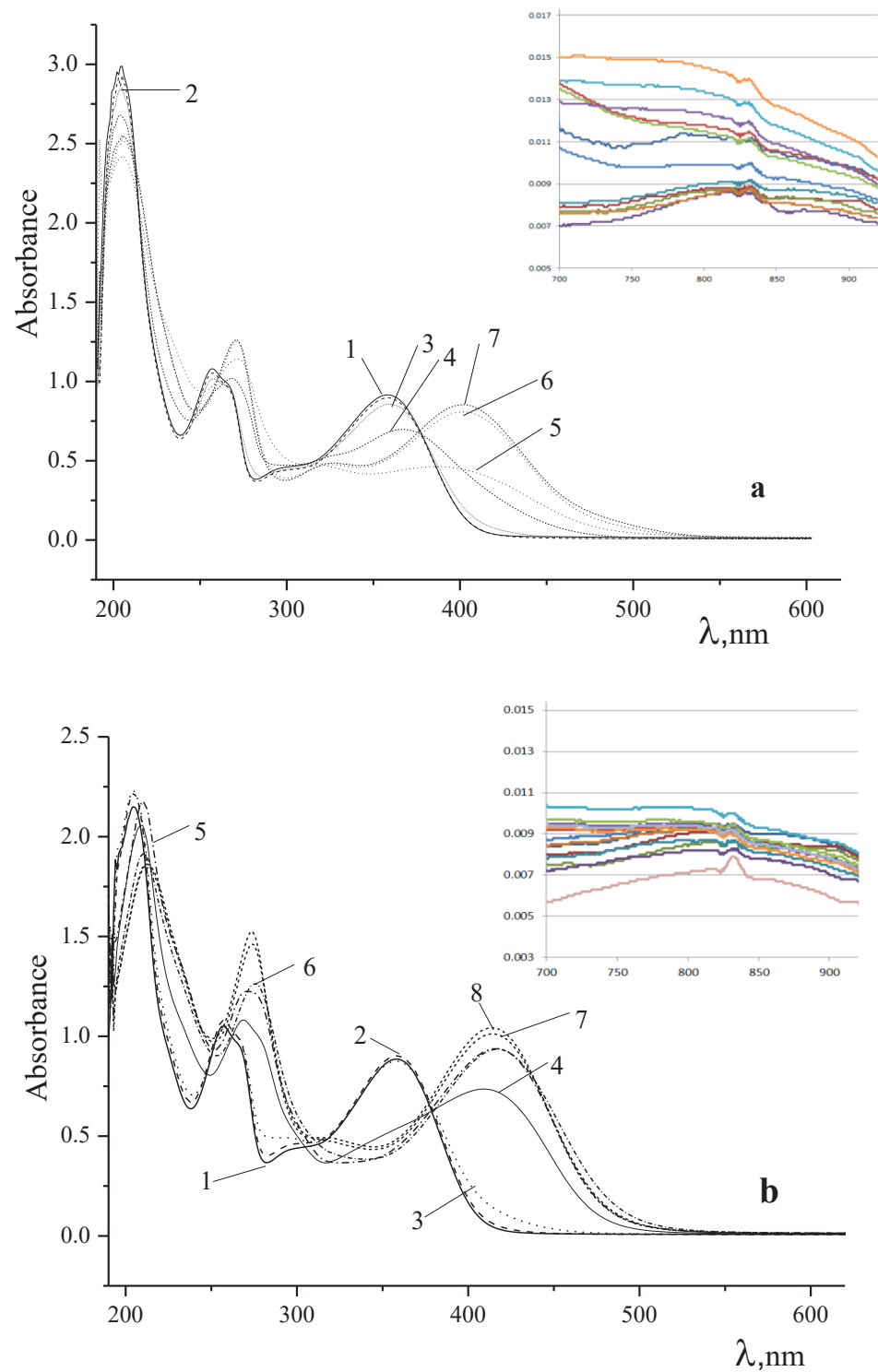

Fig. 5 UV spectra of systems as a function of pH: a - Co: Rut=1:1 (2.56 (1); 4.16 (2); 6.5 (3); 7.52 (4); 8.44 (5); 9.79 (6); 10.48 (7)); b - Cu:Rut=2:1 (2.6 (1); 3.67 (2); 4.62 (3); 5.55 (4); 6.38 (5); 7.95 (6); 9.47 (7); $10.0(8))$. Insertion: UV spectra of systems in the range of $700-900 \mathrm{~nm}$. 


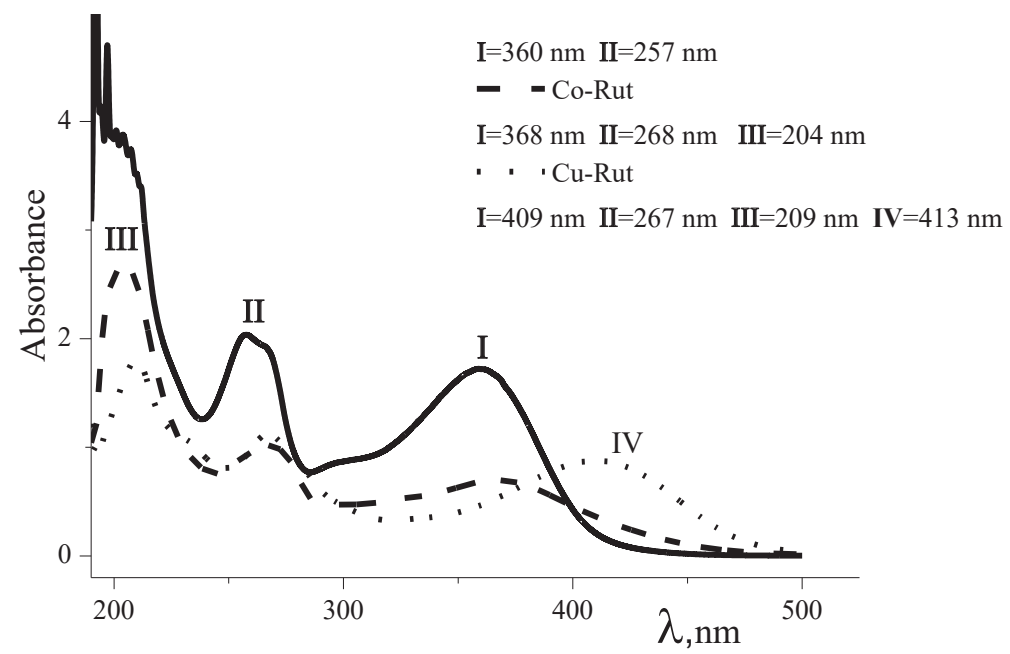

Fig.6 UV spectra of rutin and complexes CoRut, CuRut.

Regardless of the metal, for all systems, the maximum of band I shifts toward long wavelengths compared to the solution of pure rutin (Fig. 6).

For a Cu-containing system, band $\mathrm{I}$ is strongly shifted to the visible region by $53 \mathrm{~nm}$ $\left(\lambda_{\text {max. }}=413 \mathrm{~nm}\right.$, band IV). Under similar conditions, band II of rutin in the presence of metal ions has a bathochromic shift of $\sim 10 \mathrm{~nm}$, but in the spectra of metal complexes appears band III at 204 (209) nm, which may be due to different modes of coordination of cations to the functional groups of rutin.

Figure 7 shows a comparison of electronic absorption spectra for systems with different M: Rut ratios.

In the UV spectra of copper complexes with the $\mathrm{Cu}: \mathrm{L}=2: 1$ ratio for bands II and $\mathrm{I}$, a hypsochromic shift relative to equimolar metal complex $\left(\lambda_{\mathrm{I}} 277 \rightarrow 267 \mathrm{~nm} ; \lambda_{\mathrm{II}} 420 \rightarrow 409 \mathrm{~nm}\right)$ is observed, which can be explained by the different structure of metal complex and an increase in conjugation in the heterocyclic ring. Probably, at the ratio $\mathrm{Cu}: \mathrm{L}=1: 1$, chelation occurs at the 5-OH hydroxyl group and the oxy- gen atom of the carbonyl group $(4-\mathrm{C}=\mathrm{O})$ of the $\mathrm{C}$-ring of rutin. The maximum absorption responsible for the absorption of the A-ring of rutin $(7-\mathrm{OH})$ for both systems does not actually change $(210 \mathrm{~nm})$, which indicates that the 7-OH group does not participate in complexation due to its lower protic acidity. The formation of copper complexes with a ratio of $2: 1$ occurs both due to $5-\mathrm{OH}$ and $4 \mathrm{C}=\mathrm{O}$ and due to two hydroxo groups of the catechol fragment. The different structures of the complexes are confirmed by the change in the values of optical density as a function of the $\mathrm{pH}$ of solutions (fig. 7a, inset). The catechol group is the most likely metal binding site, especially in alkaline media $(\mathrm{pH} \geq 9)$ due to the deprotonation of hydroxyls. At the ratio $\mathrm{Cu}$ : Rut = 2: 1 , the copper ion can bind to the hydroxyls of the catechol groups from two rutin molecules, which are located in orthogonal planes. The different mode of coordination of $\mathrm{Cu}$ (II) is also evidenced by the position of the bands of the $\mathrm{d}-\mathrm{d}$ transition $\mathrm{B}_{1 \mathrm{~g}} \rightarrow \mathrm{A}_{1 \mathrm{~g}}$, corresponding to planar-square complexes: $644 \mathrm{~nm}(2: 1)$ and $634 \mathrm{~nm}(1: 1)$. 

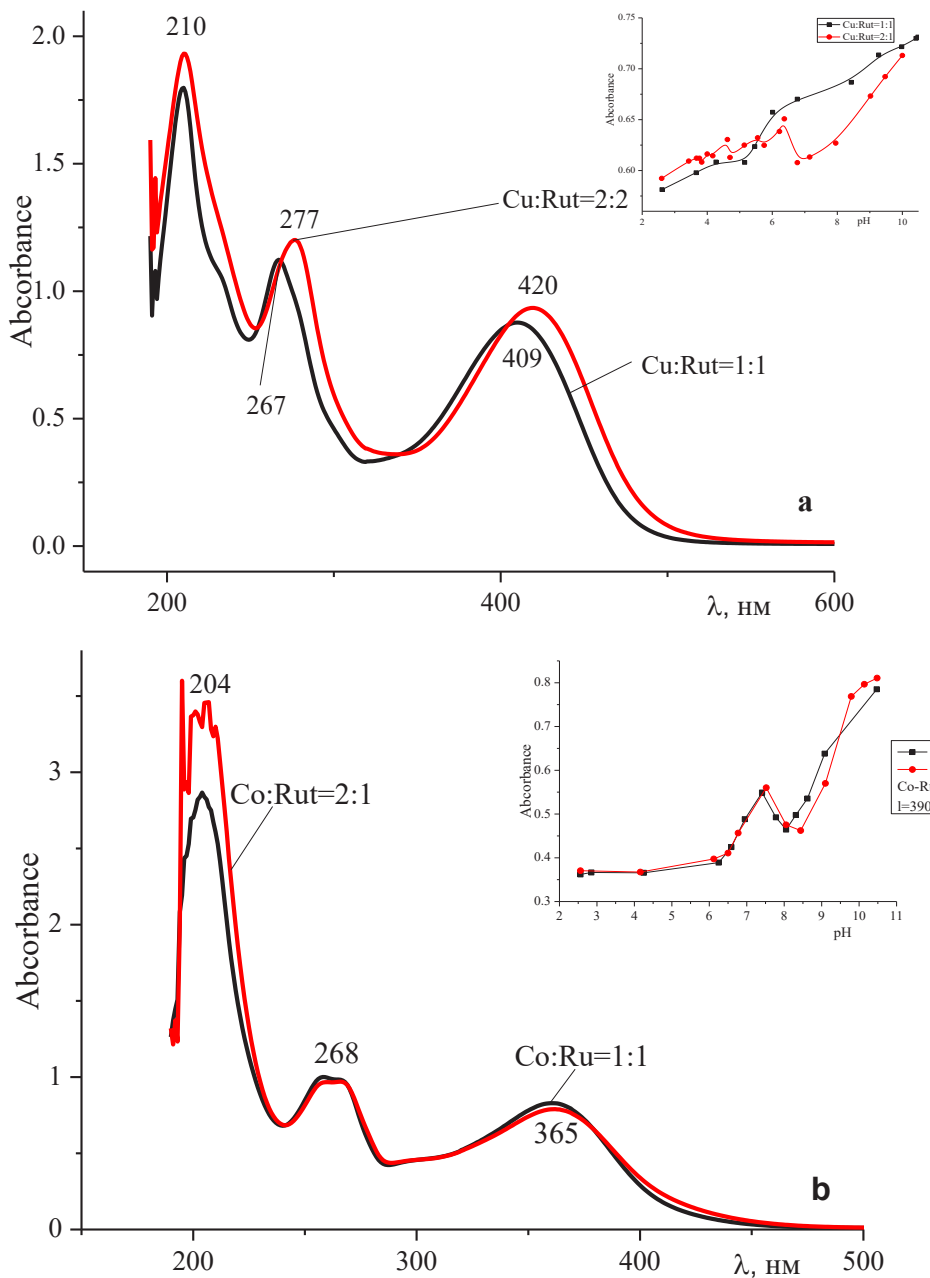

Fig. 7 Comparison of UV spectra for systems with different Cu:Rut (a), Co:Rut (b) rations (pH=6).

Insert: dependence of optical density on $\mathrm{pH}$ at ratios $\mathrm{M}:$ Rut $=1: 1 ; 2: 1$ In the electronic absorption spectra of $\mathrm{Co}(\mathrm{II})$ complexes, regardless of the Co: Rut ratio, the maxima of the absorption bands are at the same wavelength, and the course of the $\mathrm{A} \rightarrow \mathrm{pH}$ curves is the same (fig. 7, b). This indicates the formation of complexes of the same composition in both systems. However, at a ratio of 2:1, the spectral bands are split into 3 components, which may be associated with the formation of biligand complexes in which the $\mathrm{Co}^{2+}$ ion is coordinated through the catechol fragment $\mathrm{B}$ of the ring of each rutin molecule. In this case, the cobalt ion is in a distorted octahedral environment, as evidenced by the maxima of the d-d transitions in the electronic absorption spectra corresponding to the ${ }^{4} \mathrm{~T}_{1 \mathrm{~g}}(\mathrm{~F}) \rightarrow{ }^{4} \mathrm{~T}_{1 \mathrm{~g}}(\mathrm{P})$ transition in high-spin six-coordinate complexes of cobalt(II) $\left(\lambda_{\max }=508\right.$ (1:1) and $512(2: 1) \mathrm{nm})$. The bathochromic shift $\lambda_{\max }$ in the 2:1 system is due to the formation of a tetragonally deformed octahedron of $\mathrm{D}_{4 \mathrm{~h}}$ symmetry due to a significant spin-orbit interaction in the excited state ${ }^{4} \mathrm{~T}_{1 \mathrm{~g}}(\mathrm{P})$. 
According to the results of electrospray mass spectrometry, the composition of the products formed in the studied systems was determined (tabl. 3).

Table 3

The mass-to-charge ratio of fragments and their interpretation in the ESI mass spectrum of the Co (II) and Cu (II) complexes with Rut.

\begin{tabular}{c|c|c|c|c}
\hline \hline \multicolumn{4}{c|}{$\mathrm{m} / \mathrm{z}$} & \multirow{2}{*}{} \\
\cline { 1 - 4 } \multicolumn{2}{c|}{$\mathrm{Co}(\mathrm{II}):$ Rut } & \multicolumn{2}{c}{$\mathrm{Cu}(\mathrm{II}):$ Rut } & \multirow{2}{*}{ Interpretation } \\
\cline { 1 - 3 } $1: 1$ & $2: 1$ & $1: 1$ & $2: 1$ & \\
\hline 611 & 611 & 611 & 611 & $(\mathrm{~L}+\mathrm{H})^{+}$ \\
& 633 & - & 636 & {$[\mathrm{Na}(\mathrm{L})]^{+}$} \\
668 & 668 & 672 & 672 & {$\left[\mathrm{M}^{\mathrm{II}}(\mathrm{L}-\mathrm{H})\right]^{+}$} \\
726 & 725 & - & 738 & {$\left[\mathrm{M}_{2}^{\mathrm{II}}\left(\mathrm{L}-\mathrm{H}_{5,3,4}\right)\right]^{+}$} \\
& 1278 & & 1282 & {$\left[\mathrm{M}^{\mathrm{II}}\left(\mathrm{L}-\mathrm{H}_{3,4}\right) \mathrm{L}^{+}\right.$} \\
\hline \hline
\end{tabular}

The peak of protonated flavonoid $(\mathrm{m} / \mathrm{z}=611)$ is observed in all spectra. In the mass spectra of the M:Rut $=2: 1$ systems, quite intense peaks with $\mathrm{m} / \mathrm{z}=633$ and 636 appear, which correspond to the salts of rutin with Na. In addition, the ESI MS identified key characteristic fragments with $\mathrm{m} / \mathrm{z}=668$ (for $\mathrm{Co}$ ) and 672 (for $\mathrm{Cu})$, which correspond to species $\left[\mathrm{M}^{\mathrm{II}}(\mathrm{L}-\mathrm{H})\right]^{+}$, which clearly indicates the formation of metal complexes with monodeprotonated rutine molecules. In this case, the peak of the $\left[\mathrm{M}^{\mathrm{II}}(\mathrm{L}-\mathrm{H})\right]^{+}$ ion is the main one in the studied mass spectra. Also in the mass spectra there is a weakly intense peak with $\mathrm{m} / \mathrm{z}=726$ (738), which corresponds to the formation of dimeric cations $\left[\mathrm{M}_{2}^{\mathrm{II}}\left(\mathrm{L}-\mathrm{H}_{5,3,4}\right)\right]^{+}$, in which 3-d metals are coordinated by deprotonated catecholic hydroxo-groups of the ligand. In ESI MS, peaks of biligand complexes $\left[\mathrm{M}^{\mathrm{II}}\left(\mathrm{L}-\mathrm{H}_{3,4}\right) \mathrm{L}\right]^{+}$ with the inclusion of one neutral rutin molecule are recorded. Moreover, the intensity of these peaks is quite small.

CONCLUSIONS. Complex formation has been studied in the systems M (II) - Rut (M (II) $=\mathrm{Co}$ (II), $\mathrm{Cu}$ (II)) in aqueous alcohol solutions depending on $\mathrm{pH}$ and the ratio metal: ligand $=$ $1: 1 ; 2: 1$. It was shown that the structure and stoichiometric composition of the complexation reaction products are influenced by such basic parameters as L:M and the $\mathrm{pH}$ value of the medium. Depending on the $\mathrm{pH}$ value, chelation involves certain binding sites, which primarily is associated with the redistribution of the electron density in the flavonoid molecule.

In a weakly acidic or neutral medium, regardless of the $\mathrm{M}(\mathrm{II})$ : Rut ratio, the formation of monoligand complexes of rutin with 3-d metals occurs with the participation of $5-\mathrm{OH}$ and $4-\mathrm{C}=\mathrm{O}$ fragments of the $\mathrm{A}$ and $\mathrm{C}$ rings, and in an alkaline medium, chelation proceeds on the catecholic fragment of ring B rutin. Biligand complexes are formed with the participation of the gydroxo groups of the catechol fragment of each rutin molecule, and the formation of compounds with a ratio of 2:1 occurs both due to $5-\mathrm{OH}$ and $4 \mathrm{C}=\mathrm{O}$ and due to 3 ', 4'-OH groups. The calculated values of the stability constants of the complexes showed that the stability of the Co (II) complexes is several orders of magnitude lower than the stability of the corresponding $\mathrm{Cu}$ (II) complexes.

\section{ACKNOWLEDGEMENTS}

This work was supported by funding from the National Academy of Sciences of Ukraine (318 E - program), «Creation of new multifunctional nanomaterials based on coordination compounds of $3 \mathrm{~d}$-metals and lanthanides with $\mathrm{O}$, $\mathrm{N}$-donor ligands». 
СПЕКТРОСКОПЧНІ ДОСЛДЖЕННЯ КОМПЛЕКСІB Cu(II) TA Сo(II) 3 РУТИНОМ У РОЗЧИНI

\section{О. К. Трунова , М. С. Артамонов, T. О. Макотрик}

Інститут загальної та неорганічної хімії ім. В. І. Вернадського НАН України, просп. Академіка Палладіна, 32/34, Київ 03142, Україна

*e-mail:trelkon@gmail.com.

Методами електронної спектроскопії поглинання та $\mathrm{pH}$-метричного титрування вивчено комплексоутворення в системах $\mathrm{M}(\mathrm{II})-$ рутин (Rut) $(\mathrm{M}(\mathrm{II})=\mathrm{Co}, \mathrm{Cu})$ у водно-етанольних розчинах залежно від співвідношення метал:ліганд $(1: 1 ; 2: 1) \mathrm{i} \mathrm{pH}$ середовища. Показано, що на структуру та стехіометричний склад продуктів реакції комплексоутворення впливають такі основні параметри, як L:M та значення $\mathrm{pH}$ середовища. Залежно від значення $\mathrm{pH}$, в хелатуванні беруть участь певні сайти зв'язування, що, перш за все, пов'язано із перерозподілом електронної густини в молекулі флавоноїду. У слабокислому або нейтральному середовищі, незалежно від співвідношення M(II):Rut, утворення монолігандних комплексів рутину з 3-d-металами відбувається за участю 5-OH і 4-C=O фрагментів А і С кільця, а в лужному середовищі хелатування відбувається на катехольному фрагменті кільця В рутину. Білігандні комплекси утворюються за участю гідроксогруп катехольного фрагменту кожної молекули рутину, а утворення сполук у співвідношенні 2:1 відбувається як за рахунок $5-\mathrm{OH} \mathrm{i} 4 \mathrm{C}=\mathrm{O}$, так і за рахунок 3', 4'-ОН груп. Розрахова- ні значення констант стійкості комплексів показали, що стійкість комплексів Со(II) на кілька порядків нижча за стійкість відповідних комплексів $\mathrm{Cu}(\mathrm{II})$.

Ключові слова: комплекс, мідь, кобальт, рутин, флавоноїди, електронна спектроскопія.

\section{REFERENCES}

1. Chebil L., Humeau C., Anthoni J., Dehez F., Engasser J.-M., Ghoul M. Solubility of Flavonoids in Organic Solvents. J. Chem. Eng. 2007. 52: 1552 .

2. Tarakhovsky Yu.S., Kim Yu.A., Abdrasilov B.S., Muzafarov E.N. Flavonoids: biochemistry, biophysics, medicine (Pushchino: Synchrobook, 2013) [in Russian].

3. Malesev D., Kuntic V. Investigation of metalflavonoid chelates and the determination of flavonoids via metal-flavonoid complexing reactions. J. Serb. Chem. Soc. 2007, 72: 921.

4. Oyvind M., Kenneth R. Markham Andersen Flavonoids: Chemistry, Biochemistry and Applications.(CRC Press Taylor \& Francis Group, 2006).

5. Heim K.E., Tagliaferro A.R., Bobilya D. J. Flavonoid antioxidants: chemistry, metabolism and structure-activity relationships. J. Nutrit. Biochem. 2002.13: 572 .

6. Cushnie T.P., Lamb A.J. Antimicrobial activity of flavonoids. J Antimicrob Agents. 2005. 26 (5): 343.

7. Yang J., Guo J., Yuan J. In vitro antioxidant properties of rutin. Food Science and Technology. 2008. 41 (6): 1060.

8. Crozier A., Jaganath I.B., Clifford M.N. Dietary phenolics: chemistry, bioavailability and effects on health. Nat Prod Rep. 2009. 26: 1001.

9. Marzena Symonowicz, Mateusz Kolanek. Flavonoids and their properties to form chelate Complexes. Biotechnol Food Sci. 2012. 76 (1): 35-41. 
10. Al-Dhabi, N. A., Arasu, M. V., Park, C. H., \& Park, S. U. An up-to-date review of rutin and its biological and pharmacological activities. EXCLI journal. 2015. 14: 59.

11. Ganeshpurkar A., Saluja A.K. The pharmacological potential of rutin. Saudi pharmaceutical J. 201725 (2): 149.

12. Kuzniak A., Pusz J., Maciolek U. Potentiometric study of Pd (II) complexes of some flavonoids in water-methanol-1, 4-dioxane-acetonitrile (MDM) mixture. Acta poloniae pharmaceutica. 2017. 74 (2): 369.

13. Erkoc S., Erkoc F., Keskin N. Theoretical investigation of quercetin and its radical isomers. J. Mol. Struct. Theochem. 2003. 631: 141.

14. Satterfield M. Brodbelt J.S. Enhanced Detection of Flavonoids by Metal Complexation and Electrospray Ionization Mass Spectrometry. Anal. Chem. 2000. - P. 5898-5906.

15. Kasprzak M. M., Erxleben A., Ochocki J. Properties and applications of flavonoid metal complexes. RSC Advances. 2015 5(57): 45853.

16. Hu Y.J., Yue H.L., Li X.L., Zhang S.S., Tang E., Zhang L.P. () Molecular spectroscopic studies on the interaction of morin with bovine serum albumin. J.Photochem.Photobiol.B. 2012. 112: 16.

17. Grazul M., Budzisz E. Biological activity of metal ions complexes of chromones, coumarins and flavones. Coordin.Chem. 2009. 83: 363.

18. Ravishankar D., Rajora A.K., Greco F., Osborn H.M. (). Flavonoids as prospective compounds for anti-cancer therapy. The international journal of bioch. \& cell biology. 2013. 45 (12): 2821.

19. Selvaraj S., Krishnaswamy S., Devashya V., Sethuraman S., Krishnan U.M. Flavonoid-metal ion complexes: a novel class of therapeutic agents. Medicinal Research Reviews, 2014. 34(4): 677.

20. Kostyuk V.A., Potapovich A.I., Vladykovskaya E.N., Korkina L.G., Afanas'ev I.B. Influence of metal ions on flavonoid protection against asbestos-induced cell injury. Arch Biochem Biophy. 2001. (385): 129.
21. De Souza R.F., Sussuchi E.M., De GiovaniW.F. (). Synthesis, electrochemical, spectral, and antioxidant properties of complexes of flavonoids with metal ions. Synthesis and reactivity in inorganic and metal-organic chemistry. 2003.33 (7): 1125.

22. Bratu M.M., Birghila S.E.M.A.G.H.I U.L., Miresan H., Negreanu-Pirjol T., Prajitura C., Calinescu M. Biological activities of Zn (II) and $\mathrm{Cu}$ (II) complexes with quercetin and rutin: Antioxidant properties and UV-protection capacity. Rev. Chim.(Bucharest). 2014. 65: 544.

22. Khater M., Ravishankar D., Greco F., Osborn H. Metal complexes of flavonoids: their synthesis, characterization, and enhanced anti-oxidant and anti-cancer activities. Future Medicinal Chemistry 2019. 11 (21): 2845.

23. Brown J.E., Khodor H, Hider R.C., Rice-Evans C.A. Structural dependence of flavonoid interactions with $\mathrm{Cu}^{2+}$ ions: implications for their antioxidant properties. Biochemical Journal. 1998. 330 (3): 1173.

24. Anafas'ev I.B., Ostrakhovitch E.A., Mikhal V., Ibragimova L., Korkina G.A. Enhancement of antioxidant and anti-inflammatory activities of bioflavonoid rutin by complexation with transition metals. Biochem Pharmacol. 2001. 61: 677.

25. Takamura K., Sakamoto M. Spectrophotometric Studies on flavonoid-Copper(II) Complexes in Methanol Solution. Chem. Pharm. Bull. 1978. 26 (8): 2291.

26. Malešev D., Radović Z., Jelikić-Stankov M., Bogavac M. Investigation of Molybdate(II)-Rutin Complex and the Determination of theDissociation Constant of Rutin in Water-Ethanol Mixture. Analytical Letters. 1991.24 (7): 1159.

27. Kuzniak A., Pusz J., Maciolek U. (). Potentiometric study of Pd (II) complexes of some flavonoids in water-methanol-1, 4-dioxane-acetonitrile (MDM) mixture. Acta poloniae pharmaceutica. 2017. 74(2): 369.

28. Zhang L., Liu Y., Wang Y., Xu M., Hu X. UVVis spectroscopy combined with chemometric 
study on the interactions of three dietary flavonoids with copper ions. Food chemistry. 2018. 263: 208.

29. Peng B., Li R., Yan W. Solubility of rutin in ethanol+ water at (273.15 to 323.15) K. Journal of Chemical \& Engineering Data. 2009. 54(4): 1378.

30. Zi J., Peng B., Yan W. Solubilities of rutin in eight solvents at $\mathrm{T}=283.15,298.15,313.15$, 323.15, and 333.15 K. Fluid Phase Equilibria. 2007. 261(1-2): 111.

31. Williams D., Metals of Life . (M.: Mir, 1975) [in Russian].

32. Pribil R., Komplexone in der chemischen Analyse (VEB Deutscher Verlag der Wissenschaften, Berlin, 1961).

33. Saprykova Z.A. Boos G.A., Zakharov A.V. Physicochemical methods for the study of coordination compounds in solutions (Kazan: Publishing House. Kazan University, 1988) [in Russian].

34. Bukhari S.B., Memon S., Mahroof Tahir M., Bhanger M.I. () Synthesis, characterization and antioxidant activity copper-quercetin complex.
Spectrochim. Acta Part A: Molecular and Biomolecular Spectroscopy. 2009. 71(5): 1901.

35. Kholin Yu.V. Quantitative physicochemical analysis of complexation in solutions and on the surface of chemically modified silicas: meaningful models, mathematical methods and their applications. - (Kharkiv: Folio, 2000) [in Russian].

36. Graciela M. Escandar, Luis F. Sala Complexing behavior of rutin and quercetin. Can. J. Chem. 1991. 69 (12): 1994.

37. Lipkovska N.A., Barvinchenko V.N., Fedyanina T.V., Rugal A.A. Physicochemical Properties of Quercetin and Rutin in Aqueous Solutions of Decamethoxin Antiseptic Drug. Russian Journal of Applied Chemistry. 2014.87 (1): 36.

38. Torreggani A., Tamba M., Trinchero A., Bonora S. Copper (II)-Quercetin complexes in aqueous solutions: spectroscopic and kinetic properties. J. Molec. Struct. 2005. 744: 759.

39. Bjerrum Ya. Formation of metal amines in an aqueous solution (Theory of reversible step reactions). (M.: IL, 1961) [in Russian].

Стаття надійшла 16.11.2021. 